\title{
THE RELATIONSHIP BETWEEN THE SERUM LIPIDS AND THE DEVELOPMENT OF ISCHAEMIC HEART DISEASE
}

By B. BRONTE-STEWART, M.D., M.R.C.P. Clinical Nutrition Research Unit, Department of Medicine, University of Cape Town

Table 1.-Distribution of Cholesterol Between the Lipoprotein Fractions (Adapted from Barr (1953), and other data)

\begin{tabular}{|c|c|c|c|c|}
\hline & $\begin{array}{l}\text { Total cholesterol } \\
\text { mg. per } 100 \mathrm{ml} \text {. }\end{array}$ & $\underset{\%}{\text { Alpha }}$ & $\begin{array}{c}\text { Beta } \\
\%\end{array}$ \\
\hline $\begin{array}{l}\text { Dog: } \\
\quad \text { Normal } \ldots \\
\text { With atheroma }\end{array}$ & $\begin{array}{ll}\cdots & . \\
. . & .\end{array}$ & $\begin{array}{r}210 \\
2,000\end{array}$ & $\begin{array}{r}83 \\
6\end{array}$ & $\begin{array}{l}17 \\
94\end{array}$ \\
\hline $\begin{array}{l}\text { Rabbit: } \\
\quad \text { Normal } \ldots \\
\text { With atheroma }\end{array}$ & $\begin{array}{ll}\cdots & \cdots \\
\cdots & \cdots\end{array}$ & $\begin{array}{r}51 \\
2,000\end{array}$ & $\begin{array}{r}53 \\
9\end{array}$ & $\begin{array}{l}47 \\
91\end{array}$ \\
\hline $\begin{array}{l}\text { Human: } \\
\text { At birth } \\
\text { American female } \\
\text { Bantu male } \\
\text { American male } \\
\text { With ischaemic hear }\end{array}$ & $\begin{array}{l}(\ddot{1}-35 \text { yrs.) } \\
(45-65 \text { yrs.) } \\
40-49 \text { yrs.) } \\
18-35 \text { yrs.) } \\
45-65 \text { yrs.) } \\
\text { tdisease .. }\end{array}$ & $\begin{array}{r}65 \\
187 \\
252 \\
168 \\
197 \\
239 \\
259\end{array}$ & $\begin{array}{l}43 \\
34 \\
24 \\
28 \\
25 \\
22 \\
14\end{array}$ & $\begin{array}{l}57 \\
66 \\
76 \\
72 \\
75 \\
78 \\
86\end{array}$ \\
\hline
\end{tabular}

Much of the research on ischaemic heart disease today throughout the world is concerned solely with changes in the serum lipids. In certain instances, hypotheses on the pathogenesis of ischaemic heart disease have been founded merely on such changes. It becomes, then, a matter of paramount importance to examine how closely this relationship exists, and on its closeness will depend the validity of many of the hypotheses propounded.

Few will doubt the very close relationship that exists in the experimental animal between changes in the serum lipids and the development of atherosclerosis. This has been known for nearly half a century (Anitschkow, 1933). During the course of the experiment, the serum 'usually would become lipaemic with a rapid rise in the serumcholesterol level and an alteration in the distribution of the serum cholesterol between the two lipoprotein fractions, in that a greater proportion of the cholesterol would be found in the beta fraction and less in the alpha fraction. The higher the cholesterol level, the more rapidly would atherosclerosis ensue. In these acute short-term experiments, if the serum-cholesterol level did not become elevated in one of the group no atherosclerosis would be seen in that particular animal.
The resultant arterial lesion had certain similarities with atheroma in man but certain features were lacking and, due largely to the concomitant gross hypercholesterolaemia and organ lipoidosis, application of such experiments to the problem of atherosclerosis in man became a controversial issue. The experiments were designed to be short-term, a situation hardly analagous to that in man, and, furthermore, although occlusion of the smaller intramuscular branches of the coronary arteries occurred and occasionally areas of fibrosis were seen in a patchy distribution throughout the myocardium, no lesion typical of myocardial infarction could be produced by these means.

The position in man is less clear, however. In certain diseases, such as diabetes mellitus and $N$ essential xanthomatosis, a disordered fat metabolism exists and there is an increased tendency towards severe atherosclerosis and a higher incidence of ischaemic heart disease. The lipid metabolic derangement resembles that seen in 0 patients affected by ischaemic heart disease. This, added to the great accumulation of data from clinical, epidemiological and experimental sources, could suggest that ischaemic heart disease results from a disorder in fat metabolism. Much of this, unfortunately, is based on associations and extra- 
polations, and parallelism of trends need not indicate causal connection. In addition, the terms atherosclerosis and ischaemic heart disease have been used synonymously, as it is generally assumed that the latter arises on the basis of the former. Certain data indicate that this may not be so, which could suggest that mechanisms underlying the development of the one may not be common to the development of the other.

\section{Serum Lipid Abnormalities in Patients with} Ischaemic Heart Disease

\section{Oral Fat Tolerance Test}

There are several studies now to show that the lipaemia following the feeding of a standard fat meal is more intense and more prolonged in patients than in age-matched controls (Barritt, 1956; Bronte-Stewart and Blackburn, 1958). Even in the fasting state the patients have a greater opalescence of the serum. Usually, considerable overlap between patient and control groups occurs, and it is not until late in the lipaemic phase that the differences become statistically significant. Due to this, it has been claimed that the patients lack a sufficiency of the clearing factor, and this claim has been substantiated by certain experiments using heparin to activate the clearing mechanism (Oliver and Boyd, 1953). Others, however, have been unable to confirm this view and have found that the heparin-activated clearing mechanism and the respective plasma lipid substrates are similar in both affected and unaffected individuals (Mitchell and Bronte-Stewart, 1959). The significance of these findings of oral fat tolerance tests has yet to be elucidated as the lipaemic response to the same fat in the same individual is very variable and may be dependent on the amount and nature of the dietary fat intake prior to the test (Pomeranze et al., 1954; BronteStewart and Blackburn, 1958).

\section{Cholesterol Lipoprotein System}

The most publicized metabolic difference between affected and unaffected individuals concerns the cholesterol lipoprotein complex in the serum. Fats, as such, are insoluble in blood serum or other watery media in the body, whereas lipoproteins are readily soluble. To be absorbed and transported about the body, fats must be combined with cholesterol and proteins in the soluble form of lipoproteins. When these lipoproteins are estimated by means of the ultracentrifuge, affected individuals have higher values of the low-density beta lipoproteins of flotation rates Sf 12-20 and $35^{-100}$, and from the values can be calculated an intricate index, called the atherogenic index, which has been claimed to indicate the presence of the disease (Gofman et al., I954). Electrophoretically, two major lipoprotein classes occur, the alpha or faster migrating component, and the beta. Both fractions contain cholesterol, cholesterol ester, phospholipid, triglyceride and protein, but they are present in different proportions.

The serum lipoprotein pattern is different in different species, and in man is influenced by both age and sex (Table r). Individuals affected with ischaemic heart disease have a higher beta-lipoprotein and a lower alpha-lipoprotein level than agematched controls. As the alpha fraction contains more phospholipid than the beta fraction, this is thought to be the explanation for the higher cholesterol-phospholipid $(\mathrm{C} / \mathrm{P})$ ratio found in the serum of affected individuals (Gertler and White, 1954). Recently, attention has been focused on a faster-moving component in the beta-lipoprotein fraction, called the pre-beta lipoprotein, and this fraction has been noted as a transient phenomenon in the early weeks following myocardial infarction (Smith, 1957).

Far greater emphasis has been placed on the more easily estimated serum cholesterol. As yet there is no evidence to contradict its use as a reflector of disturbances in lipoprotein metabolism, or that it is inferior to the ultracentrifugal pattern in predicting manifest ischaemic heart disease (Lawry et al., 1957). Comparisons between affected and unaffected individuals have shown that the former not only possess on the average greater concentrations of serum total cholesterol, but the distribution is altered in that more is present in the beta-lipoprotein fraction and less in the alpha lipoprotein (Barr et al., I95 I ; Barr, I953; Oliver and Boyd, I955). These differences in serum-cholesterol levels are seen to their best advantage on comparisons between younger men and when the manifestation of ischaemic heart disease was myocardial infarction and not angina pectoris. In men over 50 years, mean differences between affected and unaffected individuals have been as little as between 10 and $20 \mathrm{mg}$. per $100 \mathrm{ml}$. (Biorck et al., 1957; Lawry et al., 1957). Oliver (1958), emphasizing the importance of age in this difference, expresses it in a different way. On including the cholesterol-phospholipid $(C / P)$ ratio and the alpha-beta lipoprotein ratio in addition to the serum-cholesterol level, he found that 48 per cent. of the group with ischaemic heart disease aged 60 to 69 years had 'normal' values, whereas under the age of 40 , less than ro per cent. had ' normal' values.

It will be seen, then, that in individuals with clinically manifest ischaemic heart disease, the reported biochemical abnormalities are seen only on group comparisons. Considerable overlap occurs with the unaffected groups. A case could be made for the view that these differences are the result and not the cause of the disease, except for 
the fact that in the prospective Framingham study (Dawber et al., 1957) those with high serumcholesterol levels were more liable to ischaemic heart disease than those with low values. Nevertheless, particularly at the age when the disease is most common, the serum-cholesterol-lipoprotein abnormalities at present recognized in ischaemic heart disease cannot be used with confidence to predict its development in the individual.

\section{Epidemiological Evidence for a Disorder in Lipid Metabolism}

By its very nature, the disease accounts for the absence of any reliable measure of its presence in the living. It has protean manifestations, with an onset that may be insidious, or so abrupt that in a susceptible area an individual in a short space may have to leave the unaffected or control group for the affected group. This could, in part, possibly account for the considerable overlap in studies done on very susceptible populations.

Despite wide differences in the mothers, newborn infants, irrespective of their racial origin, have similar serum-cholesterol levels (Bersohn and Wayburne, 1955). Deviations then begin to occur, and by age 20 significant differences in the serum-cholesterol levels can be seen, not only between races but between income groups within the same race (Bronte-Stewart, 1957).

Table 2.-Serum Cholesterol mg. Per ioO ML. Men AGED 20-29 YEARS

\begin{tabular}{|c|c|c|c|}
\hline & Bantu & Coloured & European \\
\hline $\begin{array}{l}\text { Low income } \\
\text { High income }\end{array}$ & $\begin{array}{l}122.5 \\
178.0\end{array}$ & $\begin{array}{l}146.1 \\
185.1\end{array}$ & $\begin{array}{l}188.3 \\
223.0\end{array}$ \\
\hline
\end{tabular}

Serum cholesterol levels (mg. per $100 \mathrm{ml}$.) of young men residing in the same area. Income grading applies to the particular racial group, for example, high-income Bantu are on a lower economic plane than low-income Europeans.

In the more prosperous peoples, peoples with a high prevalence of ischaemic heart disease, the serum-cholesterol levels steadily rise, thereafter to reach a maximum in the male at about 50 years of age. In peoples in whom ischaemic heart disease is rare, such as the South African Bantu, the Chimbu of New Guinea (de Wolfe and Whyte, 1958), and the Japanese (Keys et al., 1958), this rise with age is not seen.

- The serum-cholesterol levels of men exceed those of women throughout the period of life when the sex ratio in prevalence of the disease is very prominent. After the sixth decade the levels for the female reach and surpass those for the male (Lawry et al., 1957).

During the war years in Europe, when a sharp fall in the prevalence of ischaemic heart disease was

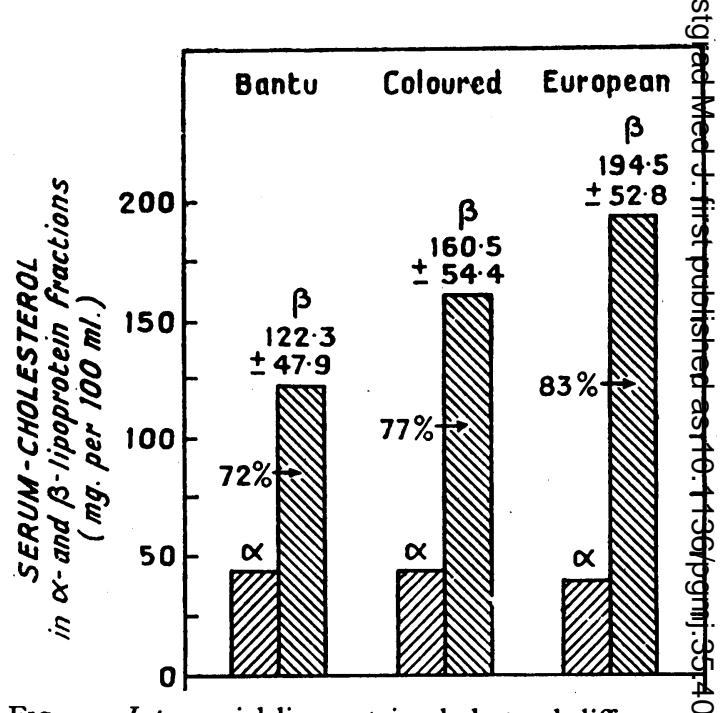

FIG. I.-Inter-racial lipoprotein cholesterol differences Mean serum-cholesterol levels (in alpha and beta lipoprotein fractions) in 132 Bantu, 117 coloureg and II4 European men aged 40-49 years, all resident in Cape Town. (Adapted from Bronte Stewart, Keys and Brock, 1955.)

noted, lower serum-cholesterol levels were re corded from many of the countries subjected the deprivations of the war (Gsell, 1948). OI Germany, an increase in serum-cholesterol tevel occurred in groups studied in 1947 and agais 1949 (Schettler, 1950). Other intra-racial di ferences are seen when one compares Japanes who have remained in Japan with those who hat emigrated to come under the American way of life on Hawaii or in Los Angeles (Fig. 2). In the latter, ischaemic heart disease is more prevalent, and serum-cholesterol levels are higher than those who have remained in Japan (Keys et a? 1958).

Parallel with these changes in the total serum cholesterol level, run differences in the manner in which it is distributed between the two lipoprote fractions. Masculinity and age tend to influence a distribution characterized by the major portion of the cholesterol being in the beta fraction (Table I). In populations with a low degree susceptibility to the disease, this does not appea to be the case (Fig. I). For example, Bantu ans Japanese males have a cholesterol distribution bo tween the lipoprotein fractions resembling that the younger European females.

It would seem, therefore, that in comparisons between populations with wide differences prevalence of the disease, ischaemic heart diseas? is associated with an abnormality of lipid metabolism. Unfortunately, in this epidemiologica্여 approach lie several variables difficult to controt Amongst them may be another factor, genetic of 




FIG. 2.-Intra-racial lipoprotein cholesterol differences. Mean serum-cholesterol levels (in alpha and beta lipoprotein fractions) in Japanese men aged 40-49 years, resident in Japan, Hawaii and U.S.A. (Adapted from Keys et al., r958.)

environmental, as yet undisclosed, that accounts for the particular findings recorded.

\section{The Chemistry of the Atheromatous Plaque}

A strengthening link in this association between abnormal blood lipids and atherosclerosis arose from the early chemical studies on the atheromatous plaque, which revealed that the fat within the plaque resembled that within the blood plasma (Weinhouse and Hirsch, 1940). Upon this grew up the filtration theory of the pathogenesis of the atheromatous plaque. This theory (Page, 1954) implied that the lipid infiltration into the intima was the primary process and that the other major component of the plaque, fibrous tissue, developed subsequently as a reaction to the presence of this fat. The centrifugal forces of the circulation drove the fat in contact with the arterial intima. Over the years, lipid deposition would accumulate and would be accelerated or intensified in the presence of blood lipid in excess amount or abnormal form, if the intraluminar or lateral filtration pressure within the artery was high, or if the vascular endothelium was abnormally permeable. This theory supplied a satisfactory explanation for the particular localization of the plaque at the origins of branches, at other sites of pressure or velocity change within the circulatory system, and for the increased severity of atherosclerosis in the presence of hypertension and such disorders of lipid metabolism as diabetes mellitus and essential xanthomatosis.
Data accumulated to suggest that the lipids did exist in abnormal form. Moreton's (1950) nephelometric studies on the chylomicra following fat feeding, suggested that it was the bio-physical state of suspension that may govern individual susceptibility to atherosclerosis, in that prolongation of the lipaemic phase would allow prolonged contact of abnormal lipids with the arterial intima and subsequent deposition. It is cholesterol, particularly, that is in high concentration in the lipid of the atheromatous plaque. Other theories on deposition, then, centred around quantitative and qualitative differences in the serum-cholesterol levels. Lewis's (1958) data are very suggestive in this regard. He analysed the cholesterol ester fatty acids in Bantu and White individuals, the latter with and without ischaemic heart disease, and the cholesterol ester fatty acids in atheromatous coronary arteries. He found that the proportion of saturated and oleic acids in the cholesterol ester was far higher in the atheromatous plaque than in the plasma, while in the plasma itself it was highest in subjects with established ischaemic heart disease and lowest in the Bantu. Furthermore, Rutstein et al. (1958), in tissueculture studies on aortic cells, showed that intracellular cholesterol was greatest when the more saturated fatty acids were present in the medium in which the cells were being grown. The possibility exists, then, that when the cholesterol ester fatty acids are unduly saturated, deposition in the arterial intima follows.

These data are certainly not proof that the fat in the atheromatous plaque originates from abnormal blood lipids. Chernick et al. (1949) have demonstrated that the arterial wall is capable of synthesizing cholesterol. Paterson and Derrick (1957) failed to find a relationship between the total serum-cholesterol levels and the total lipid subsequently extracted from large segments of the coronary arteries of these subjects. It should be emphasized, however, that the age range of their subjects was 60 to 89 years, the period of life during which biochemical differences are not marked. Blankenhorn et al. (1956) have demonstrated the presence of the fat-soluble carotenoid pigment in atheromatous plaques. As the carotenes cannot be synthesized in the human body, and in electrophoretic studies the pigment migrates with the beta-lipoprotein fraction, this finding provides very suggestive evidence that at least some of the fat present in the atheromatous plaque is deposited there.

\section{The Relationship of Coronary Atherosclerosis to Ischaemic Heart Disease}

The balance of this evidence would imply that atherosclerosis is the algebraic product of time 
and a disorder in fat metabolism. Now it is generally accepted that atheroma forms the basis of occlusive coronary artery disease, but the relationship to myocardial infarction is not clear. Despite the rapid rise in mortality from ischaemic heart disease over the last few decades, Morris (195I) has claimed the incidence of severe atherosclerosis has not risen, or has even declined. His use of calcification and other criteria as the index of severity may be open to question, in that they may merely depict chronicity, but other data support the view. In the animal, atherosclerosis is easily produced, but not the classical picture of myocardial infarction. The reported sex differences in the prevalence of severe atherosclerosis at autopsy (Lober, 1953) are far less than the remarkable sex difference in the incidence of myocardial infarction (Oliver and Boyd, 1955). It is well known, too, that severe occlusive disease of the coronary arteries may exist without apparent ill effects, but the problem of relating severity of the occlusive disease to its effects is made even more difficult when one notes that, in a large proportion of cases with myocardial infarction at autopsy, no subtending occlusion was found despite careful dissection (Yater et al., I95I; Branwood and Montgomery, 1956).

It is, therefore, conceivable that in addition to atherosclerosis a process may exist for the full explanation of the clinical manifestations of ischaemic heart disease. This becomes a vital point for clarification, because if this is true little advantage might accrue from measures aimed at lowering blood-cholesterol levels. This point, too, has revived a great deal of interest in thrombotic and other mechanisms that interfere with circulatory flow, and a relationship of these mechanisms to alterations in the blood lipids has been suggested and is at present a controversial matter (Merskey and Lackner, 1959). This merely emphasizes that ischaemic heart disease may be the end result of a series of processes, not least in importance being the state of the collateral circulation and the functional status of the heart at the time of initial attack. The association, then, between the biochemical abnormalities reported in ischaemic heart disease and the prevalence of the disease is a statistical one. A considerable overlap between affected and unaffected groups exists, particularly in the age range where clinical disease is most frequently encountered. Unless more precise measurements prove the contrary, the biochemical abnormalities at present recognized in ischaemic heart disease cannot be used with confidence to predict susceptibility in the individual. It is on this background, a background which shows that there is no precise measure of the prevalence of the disease or of its development in the living, and a background where there is no unanimity on its pathogenesis or its underlying pathology, that one must study hypotheses founded merely on alterations in the blood lipids.

\section{Summary}

I. The evidence for a relationship between altered blood lipids and ischaemic heart disease is reviewed. There are two major differences between affected and unaffected individuals. Affected individuals as a group exhibit a more extensive and more prolonged lipaemia following an oral fat meal than unaffected groups. The other major difference is seen in the serum-cholesterol-lipoprotein system.

2. In the experimental animal and in epidemiological studies comparing groups with wide differences in prevalence of ischaemic heart disease, there are wide differences in the total serumcholesterol level, the manner in which it is distributed between the two lipoprotein fractions and the ultra-centrifugal lipoprotein pattern.

3. When studies are conducted on more homogeneous groups in highly susceptible areas, however, these differences are less wide and, in fact, may be insignificant in men over the age of 50 , the age at which ischaemic heart disease is most prevalent.

4. Chemical analyses of the atheromatous plaques could suggest that atheroma results from a disorder in the blood lipids, but the relationship of atherosclerosis to ischaemic heart disease needs further clarification.

5. Although highly suggestive, the evidence as yet is insufficient to state that ischaemic heart disease is the end product of a disordered fat metabolism acting over a period of time. Considerable overlap between affected and unaffected groups exist and the biochemical abnormalities at present recognized in ischaemic heart disease cannot be used with confidence to predict susceptibility in the individual.

\section{BIBLIOGRAPHY}

ANITSCHKOW, N. (1933), in 'Cowdry's Arteriosclerosis,' p. 27 Macmillan, New York.

BARR, D. P. (1953), Circulation, 8, 641.

BARR, D. P., RUSS, E. M., and EDER, H. A. (1951), Amer. F. Med., II, 480 .

BARRITT, D. W. (r956), Brit. med. F., ii, 640.

BERSOHN, I., and WAYBURNE, S. (1955), Amer. F. clin. Nutr., 4, 117.

BIORCK, G., BLOMQVIST, G., and SIEVERS, J. (1957), Acta. med. scand., I56, 493 .

BLANKENHORN, D. H., FREIMAN, D. G., and KNOWLES, H. C. (1956), Circulation, 4, 912 .

BRANWOOD, A. W., and MONTGOMERY, G. L. (1956), Scottish med. $\mathscr{F} ., \mathbf{x}, 367$.

BRONTE-STEWART, B., KEYS, A., and BROCK, J. F. (1955), Lancet, ii, I103.

BRONTE-STEWART, B. (1957), Nutrition (Lond.), I $1,60$.

Bibliography continued on page 232 
MORRIS, J. N., and CRAWFORD, M. D. (1958), Brit. med. F., ii, 14,85 .

MORRIS, J. N., HEADY, J. A., and RAFFLE, P. A. B. (1956), Lancet, ii, 569 .

MORRIS, J. N., HEADY, J. A., RAFFLE, P. A. B., ROBERTS, C. G., and PARKS, J. W. (I953), Ibid., ii, I053 and IIII.

ORDMAN, B. (1948), Clin. Proc., $7,183$.

PICK, R., STAMLER, J., ROBARD, S., and KATZ, L. N. (1952), Circulation, 6, 858.

POLITZER, W. M., and ANDERSON, I. (1957), S. Afr. f. med. Sci., 22, 23.

REGISTRAR-GENERAL, Decennial Supplement, England and Wales (1951), 'Occupational Mortality,' part I, p. I3, H.M.S.O., London.

SCHLESINGER, M. J. (1938), Amer. Heart F., 15, 528.

SCHRIRE, V., and GANT, J. (1958), in press.

SCHRIRE, V., and UYS, C. J. (1958), in press.

SELIGMAN, C. G. (1957), ' Races of Africa,' Oxford University Press, London.

SINGER, R. (1953), Amer. Anthrop., 55, 634.

SINGER, R. (1958), Amer. F. Anat., in press.

SPRAGUE, H. B. (1958), Circulation, $17, \mathrm{I}$.

SQUIRES, B. T. (1941), S. Afr. F. med. Sci., 6, 53.

STAMLER, J. (1956), Neb. St. med. F., 41, 75.

STONE, W. (1936), Trans. roy. Soc. trop. Med. Hyg., 30, 165.
THOMAS, W. A., BLACHE, J. O., and LEE, K. T. (1957), Arch. intern. Med., 100, 423.

TROWELL, H. C., and SINGH, S. A. (r956), E. Afr. med. F.,

van OYE, E., and CHARLES, P. (1952), Ann. Soc. belge Méd. trop., 32, 297.

VINT, F. W. (1937), E. Afr. med. F., 13, 332.

VOGELPOEL, L., and SCHRIRE, V. (I955), Lancet, ii, 1 I08.

WALKER, A. R. P., and ARVIDSSON, U. V. (1954), F. clin. Invest., 33, 1358 .

WALKER, A. R. P., and BERSOHN, I. (r957), S. Afr. med. f., suppl.' Medicine in South Africa,' p. 106.

WALKER, A. R. P., and SIMSON, I. W. (1958), Lancet, i, I I 26.

WASSERBURGER, R. H. (1955), Amer. F. Med., 18, 428.

WHITE, P. D. (1947), ' Heart Disease,' 3rd ed., MacMillan, New York.

WHITE, N. K., EDWARDS, J. E., and DRY, T. J. (1950), Circulation, $\mathrm{I}, 645$.

WILENS, S. L. (1947), Arch. intern. Med., 79, 29.

WOOD, P. (1956), 'Diseases of the Heart and Circulation,' 2nd ed., Eyre and Spottiswoode, London.

WORLD HEALTH ORGANISATION (1957), Techn. Rep. Ser., No. II 7 .

WORLD HEALTH ORGANISATION (I958), Techn. Rep. Ser., No. 143 .
This symposium was contributed on invitation of the editor, by the staff of the Department of Medicine, University of Cape Town, South Africa.

The original work on which many of the views are based was carried out with the financial support of many organizations, to which grateful acknowledgment is made. The Council for Scientific and Industrial Research supports the Clinical Nutrition Research Unit in the Department and has supported other parts of the studies ad hoc. Acknowledgment is also made to the National Heart Institute, Public Health Service, United States of America; the Cape Town City Council; th 8 South African Mutual Life Assurance Societ of Cape Town; Irwin and Johnson Ltd., \& Cape Town; the South African Fish Oil Producers' Association (Pty.) Ltd., of Cape Town; the A. R. Richardson Research Fund and the Senate Research Fund of the University of Cape Town.

Bibliography continued from page 202-B. Bronte-Stewart, M.D., M.R.C.P.

BRONTE-STEWART, B., and BLACKBURN, H. (1958), 'Essential Fatty Acids' (Proceedings of the Fourth International Conference held at the University of Oxford in July, 1957, on the Biochemical Problems of Lipids, p. 180, Butterworths Scientific Publications, London).

CHERNICK, S., SRERE, P. A., and CHAIKOV, I. L. (1949), F. biol. Chem., 179, 113 .

DAWBER, T. R., MOORE, F. E., and MANN, G. V. (1957), Amer.' F. publ.' Hlth., 47, No. 4, part 2, p. 4.

de WOLFE, M. S., and WHYTE, H. M. (1958), Aust. Ann. Med., $7,47$.

GERTLER, M. M., and WHITE, P. D. (1954), ' Coronary Heart Disease in Young Adults: A Multidisciplinary Study,' p. 103 Commonwealth Fund, Cambridge (Mass.), Harvard Ưniversity Press.

GOFMAN, J. W., GLAZIER, F., TAMPLIN, A., STRISOWER, B., and DE LALLA, O. (1954), Phys. Rev., 34, 589.

GSELL, O. (1948), In: Hottinger, A., Gsell, O., Uuehlinger, E. Salzmann, C., and Labhart, A., 'Hungerkrankheit, Hungerodem und Hungertuberkulose,' p. $16 \mathrm{r}$, Schwabe, Basel.

KEYS, A., KIMURA, N., KUSUKAWA, A., BRONTESTEWART, B., LARSEN, N., and KEYS, M. H. (1958), Ann. intern. Med., 48, 83

LAWRY, E. Y., MANN, G. V., PETERSON, A., WYSOCKI, A. P., O'COONNELL, R., and STARE, F. J. (1957), Amer. '尹.
Med., 22, 605.
LEWIS, B. (1958), Lancet, ii, $7 \mathrm{r}$.

LOBER, P. H. (1953), Arch. Path., 55, 357.

MERSKEY, C., and LACKNER, H. (1959), Postgrad. med. f., 윽 35, 203 .

MITCHELL, J. R. A., and BRONTE-STEWART, B. (1959), $\frac{D}{O}$

Lancet, in press.

MORETON, J. R. (1950), f. Lab. clin. Med., 35, 373.

MORRIS, J. N. (195I), Lancet, i, 69.

OLIVER, M. F. (1958), Practitioner, 180, 202.

OLIVER, M. F., and BOYD, G. S. (1953), Clin. Sci., 12, 293.

OLIVER, M. F., and BOYD, G. S. (1955), Brit. Heart f., 17, 299. స్

PAGE, I. H. (1954), Circulation, ro, I.

PATERSON, J. C., and DERRICK, J. B. D. (1957), Ibid., 16, 512 POMERANZE, J., BEINFIELD, W. H., and CHESSIN, M. (1954), Ibid., I0, 742.

RUTSTEIN, D. D., INGENITO, E. F., CRAIG, J. M., and MARTINELLI, M. (1958), Lancet, i, 545 .

SCHETTLER, G. (1950), Klin. Wschr., 28, 565.

SMITH, E. B. (1957), Lancet, ii, 9ro.

WEINHOUSE, S., and HIRSCH, E. F. (1940), Arch. Path., 29, 31.

YATER, W. M., WELSH, P. P., STAPLETON, J. F., and CLARK, M. L. (1951), Ann. intern. Med., 34, 352. 